\title{
The Lacuna of Secondary Skills Among High School Students of South Coastal Andhra Pradesh
}

Palle Manohar

Research Scholar, Dept. of English

Acharya Nagarjuna University

Andhra Pradesh, India

manoharpalle22@gmail.com

Dr.G.Chenna Reddy

Associate Prof, Dept. of English

Acharya Nagarjuna University

Andhra Pradesh, India

crgujju27@gmail.com

Abstract

The present paper covers the teaching and learning process of English language teaching in government schools of Andhra Pradesh. As the aim of the syllabus by the SCERT, Andhra Pradesh, the learners of English are expected to achieve proper communication skills to apply it in the global context. Bright and Marc Gregor (1978) have remarked that "there is no language learning without exposure" At this juncture mere knowledge of English, based upon listening, speaking, reading and writing directed towards acquisition of communication skills among high school students. The present study intended to find out the lacuna of secondary skills in English language among the students at high school level. An Oxford dictionary defines lacuna as 'an absent part'. This paper portrays the percentage of expected and 
achieved skills of the students which is technically the term called as 'Lacuna'. Most of the students are promoted to the next classes without adequate all the skills expected by the SCERT. Gradually the differences between expected and achieved skills have been increasing by the students year by year. At this juncture, it is very much needed to fill the lacuna between expected and achieved skills among the students for the strong foundation of the students in the field of communication skills.

Statement of The Problem

The researcher finds out the practical problems of English learners. As the researcher experienced personally different problems in learning English language at secondary school level, the Researcher proposed to estimate the lacuna of secondary skills of the students of selected schools among Guntur, Prakasam and Krishna districts in Andhra Pradesh. The Researcher further planned to compare certain socio-economical, Gender and Geographical problems of the English learners. To compare the achievement levels, the Researcher planned to include the ability in vocabulary, grammar, listening skill, speaking skill, reading skill and writing skill.

Purpose of The Study

To know the basic reason for lack of sufficient communication skills among Indian students in general and high school students in Guntur Prakasam and Krishna districts in Andhra Pradesh particular. It is assumed that there are different reasons including gender, socio-economical and geographical reasons to have inadequate communication skills in English language. Sometimes it appears that the social and economic background play a very important role in the academic progress of a student. Socially and economically backward learners stand behind to those who are forward both socially and economically. It is necessary to know the reasons of socio-economical forward learners to have better communication skills if they are compared to those who are lagging behind both socially and 
economically. Urban area students have an advantage of having better communication skills if they are compared to semi-urban or rural area students. It is necessary to know the reasons for such differences of communication skills among urban, semi-urban or rural area students. It is needed to find out whether there is any gender factor to have communication skills between male and female.

Importance of Secondary Skills In English

LSRW aptitudes impact the accomplishment of a person. The four noteworthy abilities of language getting the hang of, tuning in, talking, perusing and composing offer the exact key to progress. Instructing of English language while ensuring accentuation on these entire four abilities offer a phase for the students to improve their skill in this language well. Listening, speaking, reading and writing are called skills in language. Listening and speaking are known as primary skills because even an illiterate also can be master over primary skills. Whereas the secondary skills like reading and writing need some training and practice to be master over secondary skills.

Learning a language is an art. Any skill can be acquired through the continuous practice which makes it a habit. Language learning is basically 'a habit forming process, a process during which we acquire new habits' (H.E. Palmer. Principles of Language Study). Those who can practice more and more, they would become better language users. Therefore, it is very essential to develop Listening, Speaking, reading and Writing skills properly at elementary as well as secondary level. Many cases the user of language is involved in using combination of skills.

\section{Reading Skill}

Francis Bacon says that 'Some books are to be tasted, others to be swallowed and some few to be chewed and digested; that is, some books are to be read only in parts; others to be read, but not curiously; and some few to be read wholly, and with diligence and 
attention'. Francis Bacon expressed his opinion in one of his essays 'of studies". People used to do the same now and then. Even in Newspapers readers may not read all the columns and articles. Some books are left at after reading the first chapter. Sometimes the readers go through only important chapters of a book. The readers have curiosity to read some books. Most of them are movies. There are very few books people want to read them wholly again and again. Usually those books are might be holy books by religious people and study books by research scholars.

Among all the four skills like listening, speaking, reading and writing, reading skill can be given importance for effective language learning in schools. Even in the reading skill there were some types and strategies to become an effective reader at the secondary school level. There are some strategies to become an effective reader while reading at the high school level. They are...

Skimming: Harmer $(2001 ; 202)$ says that 'Skimming is the type of reading to take in a stream of discourse and understand the gist of it without worrying too much about the details'. Skimming is a type of reading some students follow it skimming is a procedure for over viewing or previewing the materials to determine the content, to review the material already read, or to determine whether the information is pertinent to the need. It is not possible to the primary or upper primary students usually. This technique is followed by the students of higher education.

Scanning: Scanning is another important technique in reading. It is to find out numbers names, dates and answers to the specific questions. If the readers want to know a date or a word or a name or a number, then the reader has to find out the correct answer through scanning technique. For example, a reader wants to know the meaning of a word in the dictionary he or she does not go through all the words forever the dictionary, then the reader 
can find on the meaning through scanning. In the same way the important or necessary information can be gone through a newspaper reader.

Intensive Reading: Richards and Renandya (2000) states that 'the goal of Intensive Reading is to provide students, detailed information of the text as well as to develop their reading skills and grammar knowledge. Intensive Reading includes study of vocabulary with proper pronunciation, spelling, meaning, usage and study of grammar such as parts of speech, sentence structures, study of translation and memorization'. Intensive reading is necessary to understand and synthesize difficult concepts. It is also necessary to go through important documents including count orders, Government orders, property documents, important applications etc.

Extensive Reading: Jacobs and Farrell. (2012) say that 'students can learn a language well if they frequently read a large number of books. This is how their writing, speaking, listening skills would be developed and their vocabulary and grammatical knowledge would also expand'. It makes learner an independent reader. The students, apart from their textbooks read story books, magazines, novels, comics, newspapers, supplementary readers for pleasure and enjoyment. This extra reading other than academic books is extensive reading. It provides students pleasure and get information.

Loud Reading: Usually loud reading enables the students to correct their mistakes and also improves pronunciation. The importance of silent reading cannot reduce the importance of loud reading. Loud reading can be done usually at the time of primary school level of language learning. It is type of motivating for the students to practice language structures. It is the best device for the students to improve their fluency and pronunciation. It is much needed for the students for the language learning very quickly. 
Silent Reading: Silent reading means without movement of lips reading silently with in self. Generally, eyes run through the lines by mentally recognizing words. Efficient reading consists of the ability to connect meaning directly with the graphic symbols.

Writing Skill

'The goal of writing is to exchange ideas through written messages. The challenges in teaching writing skills are high for teachers as student aptitudes in writing differ widely. Some require substantial assistance to develop a smooth running operation; others instinctively take-off and create meaningful designs of their own'.(Rivers \&Temperley, 1978). If students write spontaneously, opportunities to build confidence in writing must be given to them. Writing is used when the recipient of the communication is not physically present. Professionals like journalists, teachers, writers, lawyers, etc., have good opportunities to use this method of communication in their workplace while others have very few instances to resort to this method of communicating. Writing also fulfils academic function in second language teaching when used to fix the Vocabulary and structures already studied. C. Paul Verghese. (1990) says that 'The student who learns to write English has not only to cope with the mechanical problems connected with the script of the language but also with the problems of ease and fluency of expression, of grammatical and lexical accuracy and of the appropriateness of the style of writing as demanded by the occasion or situation'.

\section{Types Of Writing}

Narrative Writing: This term generally used in fiction. It includes science fiction, stories, autobiography, biography, novels etc. The function of narrative writing usually appears in the past and sometimes in the simple present times. It is to deal with sequence of events overperiod time. While teaching narrative skills the teacher has to teach how to sequence the details of using appropriate linking devices. 
Descriptive Writing: This sort of writing is most common form. This type of writing provides information about events, places, concepts, things of personal letters, writing diary, technical and scientific works are attributed as descriptive writing. Sufficient information is needed about a thing or place or person before attempting descriptive writing. The essential aspects of descriptive writing are organizing the material, focusing on the topic, vocabulary, what to work how to work etc.

Persuasive Writing: Writing about political presentations, writing and planning advertisements, writing brochures are some of the aspects of persuasive writing. These are all meant for advanced learners. So persuasive writing requires precision, good care and logicality. To influence the readers selection of refined, accurate and striking words are needed.

Expository Writing: Writing is all about writing the facts, classification, definitions instructions, illustrations etc. It covers the function of showing cause and effect of explain how the events are linked.. It is important to till what happens as a result. Not all events are clearly related as cause and effects. We need to explain the readers how events are related.

Objectives

1. To learn the standards of the Secondary Skills among High School students

2. To find out the lacuna of syllabus expectations and actual learning of reading skills among IX class students of their VIII standard students in the South Coastal Andhra Pradesh.

3. To find out the lacuna of syllabus expectations and actual learning of writing skills among IX class students of their VIII standard students in the South Coastal Andhra Pradesh. 


\section{Methodology}

The scope of the study is limited to the high school students of Guntur, Prakasam and Krishna districts in Andhra Pradesh. 360 students were taken to estimate their lacuna of communication skills in English. Further it is limited to calculate the lacuna of listening and speaking skills in English language. The students were taken belonging to different geographical places like urban, semi-urban and rural areas. Geographically Guntur, Prakasam and Krishna located beside the coastal area of Andhra Pradesh.

A total of 360 students are involved in this research survey. The data collection will be done through the use of a survey questionnaire. 360 students are selected randomly as the sample of the study. The sample consisted of 9 high school students who are studying in IX standard. 40 students were selected from each school, among forty students, twenty students were male and the remaining twenty were female. Students from different social sectors, economical background, male and female also involved in this study. The study is conducted through the help of a test and teachers questionnaire. The questions in the questionnaire are divided into two sections; the first part consisted of questions concerning personal information and the second part of the questionnaire included reading skill and speaking skill. The below tables show the participants were involved in the study to find out lacuna of high school students from the three districts of Andhra Pradesh.

Data Analysis

The lacuna of overall reading skill among VIII class students of Guntur, Krishna and Prakasam districts 


\begin{tabular}{|c|c|c|c|c|c|c|c|c|c|c|c|c|c|}
\hline \multirow[t]{2}{*}{$\begin{array}{c}\text { S.N } \\
\text { O }\end{array}$} & $\begin{array}{c}\text { NAME } \\
\text { OF THE }\end{array}$ & \multicolumn{3}{|c|}{ Guntur } & \multicolumn{3}{|c|}{ Krishna } & \multicolumn{3}{|c|}{ Prakasam } & \multicolumn{3}{|c|}{$\begin{array}{c}\text { AVERAGE } \\
\text { PERCENTAGE }\end{array}$} \\
\hline & $\begin{array}{c}\text { SCHOO } \\
\text { L }\end{array}$ & $\begin{array}{c}\text { Avera } \\
\text { ge } \\
\text { Secure } \\
\text { d } \\
\text { Marks }\end{array}$ & $\%$ & $\begin{array}{c}\text { Lacu } \\
\text { na }\end{array}$ & $\begin{array}{c}\text { Avera } \\
\text { ge } \\
\text { Secure } \\
\text { d } \\
\text { Marks }\end{array}$ & $\%$ & $\begin{array}{c}\text { Lacu } \\
\text { na }\end{array}$ & $\begin{array}{c}\text { Avera } \\
\text { ge } \\
\text { Secure } \\
\text { d } \\
\text { Marks }\end{array}$ & $\%$ & $\begin{array}{c}\text { Lacu } \\
\text { na }\end{array}$ & $\begin{array}{c}\text { Avera } \\
\text { ge } \\
\text { Secure } \\
\text { d } \\
\text { Marks }\end{array}$ & $\%$ & $\begin{array}{c}\text { Lacu } \\
\text { na }\end{array}$ \\
\hline 1 & Social & 14.13 & $\begin{array}{c}70.6 \\
6\end{array}$ & 29.34 & 13.10 & $\begin{array}{c}65.5 \\
2\end{array}$ & 34.48 & 13.43 & $\begin{array}{c}67.1 \\
5\end{array}$ & 32.85 & 13.55 & $\begin{array}{c}67.7 \\
6\end{array}$ & 32.24 \\
\hline 2 & $\begin{array}{c}\text { Economi } \\
\text { cal }\end{array}$ & 14.18 & $\begin{array}{l}70.9 \\
0\end{array}$ & 29.10 & 15.21 & $\begin{array}{l}76.0 \\
5\end{array}$ & 23.95 & 13.56 & $\begin{array}{l}67.8 \\
0\end{array}$ & 32.20 & 14.31 & $\begin{array}{l}71.5 \\
5\end{array}$ & 28.45 \\
\hline 3 & Gender & 14.13 & $\begin{array}{c}70.6 \\
5\end{array}$ & 29.35 & 13.10 & $\begin{array}{c}65.5 \\
0\end{array}$ & 34.50 & 13.42 & $\begin{array}{c}67.1 \\
0\end{array}$ & 32.90 & 13.55 & $\begin{array}{c}67.7 \\
5\end{array}$ & 32.25 \\
\hline 4 & $\begin{array}{c}\text { Geograph } \\
\text { ic }\end{array}$ & 13.89 & $\begin{array}{l}69.4 \\
5\end{array}$ & 30.55 & 14.18 & $\begin{array}{l}70.9 \\
0\end{array}$ & 29.10 & 12.59 & $\begin{array}{l}62.9 \\
5\end{array}$ & 37.05 & 13.55 & $\begin{array}{l}67.7 \\
5\end{array}$ & 32.25 \\
\hline & Total & 14.08 & $\begin{array}{l}70.4 \\
0\end{array}$ & 29.60 & 13.89 & $\begin{array}{l}69.4 \\
5\end{array}$ & 30.55 & 13.25 & $\begin{array}{l}66.2 \\
5\end{array}$ & 33.75 & 13.74 & $\begin{array}{l}68.7 \\
0\end{array}$ & 31.30 \\
\hline
\end{tabular}

The above table represents the data pertaining to the marks of the lacuna of overall reading skill among VIII class students of Guntur, Krishna and Prakasam districts. According to the data Guntur district students have $29.60 \%$ of lacuna whereas Krishna district students have $30.55 \%$, and Prakasam district students have $33.75 \%$ lacuna. The data indicates that students from all the districts have $68.70 \%$ of reading skills with $31.30 \%$ lacuna. Guntur district students' lacuna is only $29.60 \%$ because of their geographical and economical advantage. The data also indicates the lacuna of Prakasam district students is very high i.e 33.75\%. Prakasam district students have less than average skills, whereas Guntur district students have more than average skills in reading. On total the students are lagging behind to learn reading skill with $31.30 \%$ lacuna. The main reasons for the lacuna of reading skill 
among the students have inappropriate materials for the level of the students. At the same time students feel difficulty while reading the text because of not having enough vocabulary. The lacuna of overall writing skill among VIII class students of Guntur, Krishna and Prakasam districts

\begin{tabular}{|c|c|c|c|c|c|c|c|c|c|c|c|c|c|}
\hline \multirow[t]{2}{*}{$\begin{array}{c}\text { S.N } \\
\text { O }\end{array}$} & $\begin{array}{l}\text { NAME } \\
\text { OF THE }\end{array}$ & \multicolumn{3}{|c|}{ Guntur } & \multicolumn{3}{|c|}{ Krishna } & \multicolumn{3}{|c|}{ Prakasam } & \multicolumn{3}{|c|}{$\begin{array}{c}\text { AVERAGE } \\
\text { PERCENTAGE }\end{array}$} \\
\hline & $\begin{array}{c}\text { SCHOO } \\
\text { L }\end{array}$ & $\begin{array}{l}\text { Avera } \\
\text { ge } \\
\text { Secure } \\
\text { d } \\
\text { Marks }\end{array}$ & $\%$ & $\begin{array}{c}\text { Lacu } \\
\text { na }\end{array}$ & $\begin{array}{l}\text { Avera } \\
\text { ge } \\
\text { Secure } \\
\text { d } \\
\text { Marks }\end{array}$ & $\%$ & $\begin{array}{c}\text { Lacu } \\
\text { na }\end{array}$ & $\begin{array}{c}\text { Avera } \\
\text { ge } \\
\text { Secure } \\
\text { d } \\
\text { Marks }\end{array}$ & $\%$ & $\begin{array}{c}\text { Lacu } \\
\text { na }\end{array}$ & $\begin{array}{c}\text { Avera } \\
\text { ge } \\
\text { Secure } \\
\text { d } \\
\text { Marks }\end{array}$ & $\%$ & $\begin{array}{c}\text { Lacu } \\
\text { na }\end{array}$ \\
\hline 1 & Social & 12.17 & $\begin{array}{c}60.8 \\
6\end{array}$ & 36.13 & 11.93 & $\begin{array}{c}59.6 \\
5\end{array}$ & 40.35 & 11.73 & $\begin{array}{c}58.6 \\
8\end{array}$ & 41.31 & 11.94 & $\begin{array}{c}59.4 \\
2\end{array}$ & 40.27 \\
\hline 2 & $\begin{array}{c}\text { Economi } \\
\text { cal }\end{array}$ & 14.41 & $\begin{array}{l}72.0 \\
5\end{array}$ & 27.95 & 14.61 & $\begin{array}{l}73.0 \\
5\end{array}$ & 26.95 & 13.07 & $\begin{array}{l}65.3 \\
5\end{array}$ & 34.65 & 14.03 & $\begin{array}{l}70.1 \\
5\end{array}$ & 29.85 \\
\hline 3 & Gender & 12.17 & $\begin{array}{c}60.8 \\
5\end{array}$ & 39.15 & 11.92 & $\begin{array}{c}59.6 \\
0\end{array}$ & 40.40 & 11.38 & $\begin{array}{c}56.9 \\
2\end{array}$ & 43.08 & 11.82 & $\begin{array}{c}59.1 \\
0\end{array}$ & 40.90 \\
\hline 4 & $\begin{array}{c}\text { Geograph } \\
\text { ic }\end{array}$ & 11.97 & $\begin{array}{l}59.8 \\
5\end{array}$ & 40.15 & 12.75 & $\begin{array}{l}63.7 \\
5\end{array}$ & 36.25 & 11.02 & $\begin{array}{l}55.1 \\
0\end{array}$ & 44.90 & 11.91 & $\begin{array}{l}59.5 \\
5\end{array}$ & 40.45 \\
\hline & Total & 12.68 & $\begin{array}{l}63.4 \\
0\end{array}$ & 36.60 & 12.80 & 64.0 & 36.0 & 11.80 & 59.0 & 41.0 & 12.42 & $\begin{array}{l}62.1 \\
0\end{array}$ & 37.90 \\
\hline
\end{tabular}

The above table represents the data pertaining to the marks of the lacuna of overall writing skill among VIII class students of Guntur, Krishna and Prakasam districts. According to the data Guntur district students have $36.60 \%$ of lacuna whereas Krishna district students have $36.0 \%$, and Prakasam district students have $41.0 \%$ lacuna. The data indicates that students from all the districts have $62.10 \%$ of writing skills with $37.90 \%$ lacuna. Krishna district students' lacuna is only $36.0 \%$ because of their geographical and economical 
advantage. The data also indicates the lacuna of Prakasam district students is very high i.e. 41.0\%. Prakasam district students have less than average skills, whereas Krishna district students have more than average skills in writing. On total the students are lagging behind to learn writing skill with $37.90 \%$ lacuna. The reason for the lacuna of writing skill majorly is not having enough practice to develop sophisticated writing. Besides, students feel difficulty about grammar and sentence construction as a result students writing skill is uncertain.

Conclusion

It is fact that there are many problems of learning secondary skills in English language at primary school level. The main reasons for the lacuna of reading skill among the students have inappropriate materials for the level of the students. At the same time students feel difficulty while reading the text because of not having enough vocabulary. The reason for the lacuna of writing skill majorly is not having enough practice to develop sophisticated writing. Besides, students feel difficulty about grammar and sentence construction as a result students' writing skill is uncertain.It is suggested that the Task Based and Target Oriented techniques include in the teaching and learning process at the high school level. English environment needed to create like English laboratories, English speaking clubs and other cultural activities in the schools. 


\section{References}

Bright and Marc Gregor (1978) Bright, J. A. \& McGregor, G.P. (1978). Teaching English as a Second Language (p.2). London: Longman.

State Council for Education Research and Training. 2010 (SCERT)

Richard, J. C. The Context of Language Teaching, Cambridge, Cambridge University Press, 1985

Kothari, C.R. Research Methodology: Methods and Techniques, 2nd ed. New Delhi: New Age International Private Ltd. 2004. Web. 24 April 2015.

Harmer, J The Practice of English Language Teaching. 3rd edition, Pearson Education. Limited. Essex. England, 2001.

H.E. Palmer. Principles of Language Study

Francis Bacon. 'Of Studies' 